\title{
PENGARUH HUJAN PADA STABILITAS LERENG DI JALAN TOL GEMPOL - PANDAAN
}

\author{
Dewi Atikah ${ }^{1}$, Pitojo Tri Juwono², Andre Primantyo Hendrawan ${ }^{2}$ \\ ${ }^{1}$ Mahasiswa Magister Teknik Pengairan, Fakultas Teknik, Universitas Brawijaya, Malang \\ ${ }^{2}$ Dosen Jurusan Teknik Pengairan, Fakultas Teknik, Universitas Brawijaya, Malang \\ e-mail : dewi_atikah81@yahoo.com,pitojo_tj@ub.ac.id, andre_ph@ub.ac.id
}

\begin{abstract}
ABSTRAK : Jalan tol Gempol - Pandaan sta 6+275 - 6+375 hasil pengeprasan bukit mengalami kelongsoran pada tanggal 3 Februari 2015 dengan didahului oleh hujan. Studi ini bertujuan mengetahui pengaruh hujan pada stabilitas lereng di jalan tol Gempol - Pandaan. Intensitas hujan sebagai input Geostudio Seep/W, hasil analisisnya menjadi input Slope/W. Hasilnya angka keamanan saat terjadi longsor adalah 1.107 (Bishop), 1.061 (Fellenius), dan 1.101 (MorgensternPrice). Berdasarkan data hujan selama 10 tahun, intensitas $0.0077 \mathrm{~m} / \mathrm{jam}$, merupakan nilai maksimal karena setelah nilai ini tercapai, angka keamanannya tidak bisa berkurang lagi. Alternatif perkuatan soil nailing mempunyai angka keamanan 1.555921, lebih tinggi dari bored pile dan anggaran biaya lebih kecil sebesar Rp. 1.938.804.000,00 lebih kecil dari bored pile. Ambang batas hujan yang dapat memicu longsor adalah kombinasi hujan $60 \mathrm{~mm}$ dan hujan 100 mm selama 30 hari yang menghasilkan total hujan sebesar $960 \mathrm{~mm}$.
\end{abstract}

Kata kunci: stabilitas lereng, intensitas hujan, Seep/W, Slope/W, ambang batas hujan

\begin{abstract}
Gempol - Pandaan toll road at sta $6+275-6+375$ is formed by cutting hill. On February 3th, 2015 this location suffered landslide that was preceded by rainfall. This study aims to determine the effect of rainfall on slope stability in Gempol - Pandaan toll road. Rainfall intensity was apllied as input in Geostudio Seep / W and the results of Seep/W analysis became input in Slope /W. As a result, factor of safety when landslide occured was 1.107 (Bishop), 1.061 (Fellenius), and 1.101 (Morgenstern-Price). Based on rainfall data for 10 years, rainfall intensity $0.0077 \mathrm{~m} / \mathrm{h}$ was the maximum value. After this value was reached, the factor of safety cannot be reduced again. Factor of safety from soil nailing reinforcement alternative was increased 1.556, higher than bored pile application and the cost budget of soil nailing (Rp. 1,938,804,000.00) is cheaper than bored pile. The rainfall threshold value to initiate landslide is a combination of 60 $\mathrm{mm}$ rainfall and $100 \mathrm{~mm}$ rainfall for 30 days that produce total rainfall amount of $960 \mathrm{~mm}$.
\end{abstract}

Keywords: slope stability, rainfall intensity, Seep/W, Slope/W, rain threshold

Pembangunan jalan di Indonesia sering terkendala dengan kondisi ketersediaan lahan. Salah satu contoh di rencana ruas jalan Tol Gempol - Pandaan yang terkendala keberadaan bukit. Sebagai solusinya bukit tersebut digali atau dipotong. Namun bekas potongan atau galian ini ternyata dapat menyebabkan permasalahan atau kendala yang lainnya. Hal yang paling penting di daerah galian adalah masalah stabilitas lereng bekas galian. Kemungkinan terjadinya longsoran, lebih besar di daerah galian daripada timbunan karena dalam area galian rembesan air akan menuju lereng.

Pada tanggal 1 - 2 Februari 2015 terjadi hujan di daerah Gesing Randupitu dan sekitarnya. Air hujan tersebut sebagian melimpas ke bawah melalui lereng galian dan sebagian lainnya terinfiltrasi ke dalam lereng. Lereng menjadi jenuh air, lapisan shotcrete menjadi retak kemudian pecah. Pada tanggal 2 Februari 2015 tanah di bagian bawah menjembul (heaving) kemudian akhirnya longsor pada tanggal 3 Februari 2015. 
Lokasi penelitian tepatnya di Sta $6+$ $275-6+375$ atau $\mathrm{Km} \mathrm{51+100-51+200}$ terjadi kelongsoran sepanjang $100 \mathrm{~m}$ dan ketinggian $25 \mathrm{~m}$. Meskipun permukaan lereng sudah dilapisi dengan shotcrete ternyata hujan masih bisa terinfiltrasi ke dalam permukaan lereng. Lubang pori yang sudah tertanam juga tidak bisa mengalirkan rembesan air yang terjadi akibat infiltrasi air hujan. Oleh karena itu diperlukan analisa dan perhitungan ulang dengan bantuan software Geostudio.

Tujuan dilakukannya kajian ini adalah untuk mengetahui stabilitas lereng apabila dianalisis dengan metode Fellenius, Bishop dan Morgensten Price, mengetahui pengaruh hujan pada kestabilan lereng, memperoleh metode perbaikan paling tepat untuk mengatasi kelongsoran, mengetahui ambang batas hujan yang aman yang tidak menyebabkan kelongsoran.

Tanah longsor dapat diartikan gerakan massa tanah yang mengandung air, menggelincir kebawah menuruni kemiringan lereng. Gerakan tanah terjadi dari hasil gangguan keseimbangan yang merupakan hasil dari sebuah proses infiltrasi air ke dalam tanah yang berakibat pada penambahan bobot tanah. Jika air tersebut menembus sampai tanah kedap air yang berperan sebagai bidang gelincir, maka tanah akan menjadi licin dan tanah yang berada diatasnya akan bergerak mengikuti sepanjang badan lereng. Gerak masa pada lereng terjadi jika hambat geser tanah lebih kecil dari berat massa tanah.

Kejadian tanah longsor di Indonesia umumnya terjadi pada musim penghujan. Tanah pada umumnya akan berada dalam kondisi jenuh air pada musim penghujan dan mengakibatkan lereng menjadi tidak stabil. Sehingga beresiko untuk terjadi kelongsoran. Peningkatan air pori akibat pembasahan atau peningkatan kadar air pada musim penghujan, akan meningkatkan muka air tanah serta menurunkan ketahanan tanah yang bersangkutan disepanjang bidang gelincirnya.

Menurut Karnawati, 2010 hujan pemicu longsoran adalah tipe hujan deras dan tipe hujan normal tetapi berlangsung lama. Tipe hujan deras adalah hujan yang mempunyai intensitas $70 \mathrm{~mm}$ per jam atau hujan dengan intensitas lebih dari $100 \mathrm{~mm}$ per hari. Tipe hujan seperti ini hanya efektif memicu longsoran pada lereng yang tanahnya mudah menyerap air seperti tanah lempung pasiran dan tanah pasir. Tipe hujan normal adalah hujan yang intensitasnya kurang dari $20 \mathrm{~mm}$ per hari. Tipe hujan seperti ini apabila berlangsung selama beberapa minggu hingga beberapa bulan dapat efektif memicu longsoran pada lereng yang tanahnya lebih kedap air seperti tanah lempung.

Sedangkan menurut Subiyanti, 2011 hujan normal dengan durasi lama berpengaruh terhadap perubahan tekanan air pori. Hujan normal dengan durasi lama, pada tanah berbutir halus menyebabkan muka air tanah naik dan tekanan air pori juga naik. Proses penjenuhan tanah berlangsung terhadap fungsi waktu. Ketika tanah jenuh, maka kekuatan geser tanah hilang, sehingga kemungkinan besar terjadi longsor.

Seep/W adalah software yang digunakan untuk menganalisis rembesan air tanah. Fitur steady state dan transient dapat diintegrasikan pada Slope/W untuk digunakan dalam analisis kegagalan lereng secara komprehensif. Hasil analisis tersebut dapat digunakan untuk memprediksi performa lereng di masa yang akan datang akibat pengaruh kondisi iklim (Geo-Slope International).

Slope/W merupakan perangkat untuk menghitung faktor keamanan lereng tanah maupun batu. Selain itu fitur parent analysis memberikan kemudahan integrasi antara Seep/W dan Slope/W. Fitur ini dapat digunakan untuk menganalisis tekanan air pori yang dihasilkan Seep/W seperti dalam pemodelan efek curah hujan pada lereng.

Bored pile dengan diameter yang kecil maupun besar dapat digunakan sebagai dinding penahan tanah. Bored pile dipasang ke dalam tanah dengan cara mengebor tanah terlebih dahulu, baru kemudian diisi tulangan dan dicor beton. Tiang ini biasanya, dipakai pada tanah yang stabil dan kaku, sehingga memungkinkan untuk membentuk lubang yang stabil dengan alat bor. Jika tanah mengandung air, pipa besi dibutuhkan untuk menahan dinding lubang dan pipa ini ditarik ke atas pada waktu pengecoran beton. Pada tanah yang keras atau batuan lunak, dasar tiang dapat dibesarkan untuk menambah tahanan dukung ujung tiang.

Bored pile dipasang sampai kedalaman tertentu menembus lapisan keras tanah untuk menahan gerakan tanah yang akan longsor. Kedalaman bored pile harus melebihi bidang longsor potensial. Pengaruh lengkung 
(arching effect) tanah yang berada di antara bored pile, maka jarak melintang bored pile dipasang pada jarak antar as-as 3 kali diameter bored pile (Hardiyatmo, 2012). Bored pile yang dindingnya bersinggungan satu sama lain digunakan untuk menahan galian terbuka yang kedalamannya melebihi $30 \mathrm{~m}$. Karena saling bersinggungan, maka dibutuhkan sistem drainase di belakang dinding untuk menghindari tekanan air di belakangnya.

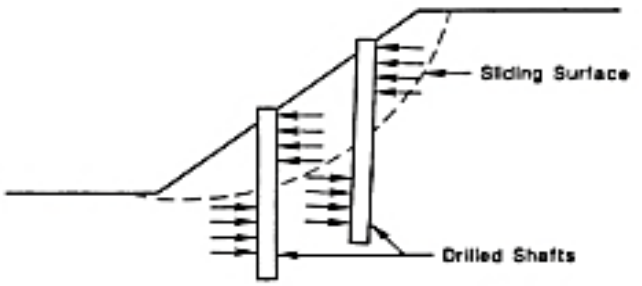

Gambar 1. Bored pile Pada Lereng (Sumber: FHWA, 2010)

Soil nailing adalah teknik konstruksi yang dapat digunakan sebagai salah satu metode untuk memperkuat kondisi lereng tanah yang tidak stabil atau sebagai teknik konstruksi yang digunakan untuk menambah keamanan bagi lereng eksisting yang telah stabil. Faktor keamanan untuk soil nailing (FHWA, 2015) adalah 1.5.

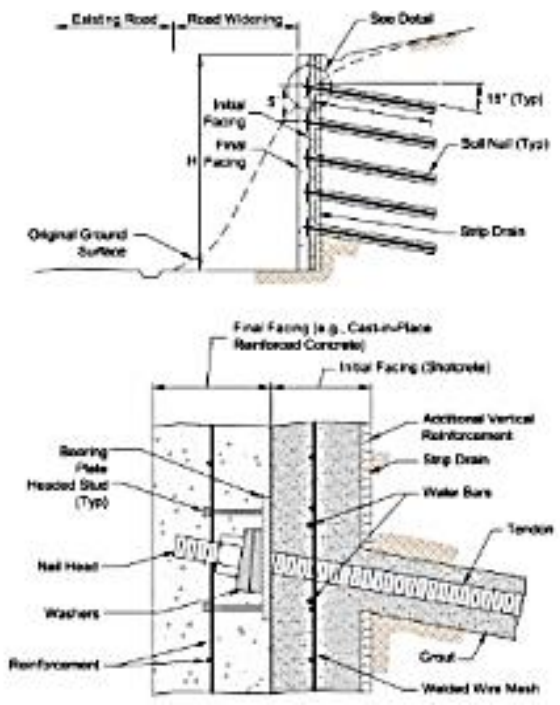

Gambar 2. Potongan Melintang Lereng Dengan Perkuatan Soil nailing

(Sumber: FHWA, 2015)

\section{BAHAN DAN METODE}

\section{Curah Hujan Rata-rata Daerah}

Untuk menghitung curah hujan rata-rata daerah menggunakan metode cara rata-rata hitung sebagai berikut :

$$
d=\frac{d_{1}+d_{2}+\cdots+d_{n}}{n}
$$

Dengan :

$\mathrm{d}=$ curah hujan rata-rata daerah $(\mathrm{mm})$

$\mathrm{n} \quad=$ banyaknya pos penakar hujan

$\mathrm{d}_{1}, \mathrm{~d}_{2}, \mathrm{~d}_{\mathrm{n}}=$ curah hujan yang tercatat di pos penakar hujan (mm)

\section{Intensitas}

Data curah hujan harian dijadikan data hujan jam-jaman dengan rumus Mononobe (Soemarto, 1995:15) sebagai berikut :

$$
i=\frac{R_{24}}{24}\left(\frac{24}{t}\right)^{2 / 3}
$$

Dengan :

$i=$ intensitas hujan $(\mathrm{mm} / \mathrm{jam} ; \mathrm{m} / \mathrm{jam})$

$t=$ waktu (durasi) curah hujan (jam)

$R_{24}=$ tinggi hujan maksimum 24 jam (mm)

Intensitas hujan yang terjadi di

Indonesia rata-rata mempunyai durasi antara 5

- 7 jam. Sehingga nilai tengah dari interval tersebut sering digunakan sebagai acuan dalam menghitung intensitas hujan jam-jaman yang berasal dari data hujan harian.

Metode Fellenius

$$
F=\frac{\text { Jumlah penahan longsor }}{\text { Jumlah penyebab longsor }}
$$

Bila terdapat air pada lereng, akibat pengaruh tekanan air pori persamaan menjadi:

$$
F=\frac{\sum_{i=1}^{i=n} \operatorname{ca} 1+(W i \cos \llbracket \theta i-\mu i \text { a } i) \operatorname{tg} \varphi \rrbracket}{\sum_{i=1}^{i=n} W i \sin \theta i}
$$

dengan ;

$\mathrm{F}=$ faktor aman

$\mathrm{c} \quad=$ kohesi $(\mathrm{kN} / \mathrm{m}$

$\varphi=$ sedut gesek dalam tanah $\left(^{\circ}\right)$

$\mathrm{Wi}=$ berat irisan tanak ke-i $(\mathrm{kN})$

ai = lengkungan irisan ke-i $(\mathrm{m})$

$\mu \mathrm{i}=$ tekanan air pori ke-i $(\mathrm{kN})$

$\theta \mathrm{i}=$ sudut antara jari-jari lengkung dengan garis kerja massa tanah

Rasio tekanan air pori :

$$
r u=\frac{\mu b}{W}=\frac{\mu}{2 h}
$$

Dengan :

$\mathrm{Ru}=$ rasio tekanan air pori

$\mu=$ tekanan air pori $\left(\mathrm{kN} / \mathrm{m}^{2}\right)$

$\mathrm{b}=$ lebar irisan ke-i $(\mathrm{m})$

$\gamma=$ berat volume tanah $\left(\mathrm{kN} / \mathrm{m}^{2}\right)$

$\mathrm{h}=$ tinggi irisan rata-rata $(\mathrm{m})$ 


\section{Tekanan Air Pori Positif}

Menurut Hardiyatmo, 2012 apabila tekanan air pori $(u)$ naik, maka tegangan normal efektif dalam tanah berkurang dan kuat geser tanah menurun. Hal ini berakibat menurunnya stabilitas lereng. Kenaikan air pori lebih cepat selama periode hujan lebat (hujan menerus). Kenaikan inilah yang menyebabkan terjadinya kelongsoran.

Kuat geser tanah $(\tau)$ dinyatakan dalam persamaan :

$$
\tau=c^{\prime}+(\sigma-u) \tan \phi
$$

Dengan:

$$
\begin{aligned}
& \mathrm{c}=\text { kohesi efektif } \\
& \sigma=\text { tegangan normal } \\
& \phi=\text { sudut geser dalam } \\
& u=\text { tekanan air pori }
\end{aligned}
$$

\section{Tekanan Air Pori Negatif}

Tekanan air pori negatif sering disebut isapan tanah atau soil suction. Butiran tanah yang kecil akan meningkatkan tekanan kapiler dan juga tekanan air pori negatif. Tekanan air pori negatif menambah tegangan efektif dan menambah stabilitas lereng (Hardiyatmo, 2012). Untuk tanah tidak jenuh, digunakan persamaan:

$$
\mathrm{C}=\mathrm{c}^{\prime}+\left(u_{\mathrm{a}}-u_{\mathrm{w}}\right) \operatorname{tg} \phi_{\mathrm{b}}
$$

Dengan :

$$
\begin{array}{ll}
\mathrm{C} & =\text { kohesi total tanah } \\
\mathrm{c}^{\prime} & =\text { kohesi efektif } \\
(\mathrm{ua}-\mathrm{uw}) & =\text { matrix suction } \\
\phi \mathrm{b} & =\text { sudut geser matrik }
\end{array}
$$

\section{Lokasi Studi}

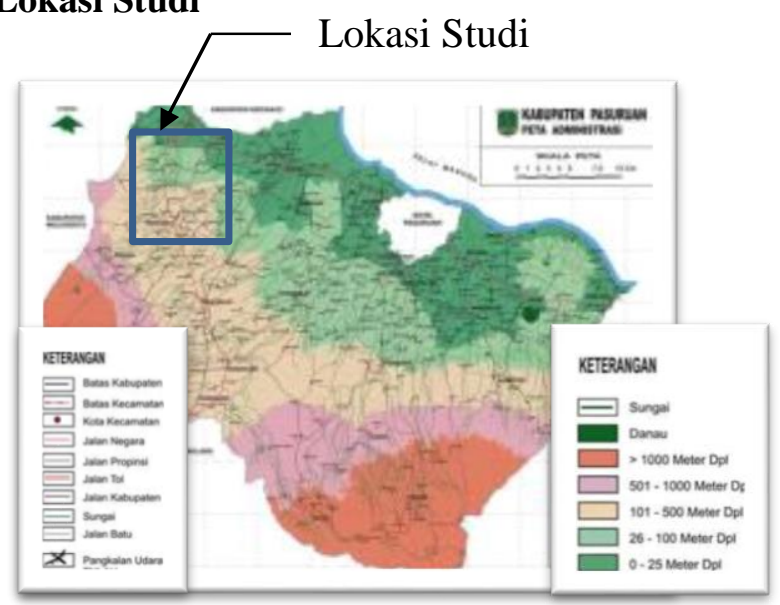

Gambar 3 Peta Lokasi Studi

(Sumber : Dinas PU Bina Marga Kabupaten Pasuruan)

\section{Pengumpulan Data}

Data yang digunakan dalam analisis stabilitas lereng ini antara lain :
1. Data gambar geometri lereng

2. Data hujan

3. Data parameter tanah

4. Data - data pelengkap lainnya.

\section{Pengolahan Data}

Adapun langkah-langkah pengerjaan studi, sebagai berikut:

1. Melakukan pengumpulan data pendukung yang digunakan dalam analisis stabilitas lereng.

2. Memprediksi propertis hidrolik tanah dengan korelasi berdasarkan data tanah yang ada.

3. Menganalisis data hujan.

4. Memodelkan lereng pada kondisi asli berdasarkan data gambar melalui program Autocad.

5. Mengimpor gambar dari Autocad ke Geostudio, Seep/W.

6. Melakukan simulasi dengan Seep/W.

7. Hasil dari Seep/W dianalisa dengan Slope/W.

8. Menginput propertis tanah untuk analisis kestabilan lereng.

9. Didapatkan faktor aman lereng dengan metode Fellenius, Bishop dan Morgensten Price.

10. Menganalisis menggunakan metode analisis Fellenius, Bishop dan Morgen-sten Price sehingga didapatkan angka keamanan.

11. Menganalisis pengaruh hujan pada stabilitas lereng berdasarkan faktor aman lereng.

12. Memodelkan lereng dengan perkuatan bored pile dan soil nailing

13. Faktor aman masing-masing perkuatan didapatkan

14. Analisis berdasarkan faktor aman terbesar dan rencana anggaran biaya terkecil.

15. Faktor aman lereng terhadap hujan yang didapatkan dengan menginput angka hujan perkiraan.

16. Analisis ambang batas curah hujan dan durasi hujan yang aman pada stabilitas lereng.

\section{HASIL DAN PEMBAHASAN Jenis Tanah}

Menurut Hidayat (2015), kondisi longsor terparah pada sta $6+325$. Karakteristik tanah pada lokasi berupa endapan vulkanik berukuran pasir lanauan yang berwarna coklat kemerah-merahan. Jenis tanah ini kebanyakan 
bersifat lepas-lepas. Material tanah yang lepas-lepas dengan ukuran butir lanau sampai bongkah menyebabkan mudah terjadi infiltrasi air hujan ke dalam tanah.

\section{Analisa Hidrologi}

Analisis hidrologi bertujuan untuk mengetahui curah hujan rata-rata yang terjadi pada daerah studi yang berpengaruh pada besarnya intensitas hujan. Analisis dilakukan terhadap data hujan harian antara tahun 2005 sampai dengan tahun 2015 (11 tahun) yang diperoleh dari stasiun pengukuran hujan di empat lokasi, yaitu stasiun Banyulegi, Kepulungan, Randupitu, dan Tanggul.

Tabel 1. Data Masukan Dalam Seep/W

\begin{tabular}{|c|c|c|c|c|c|}
\hline Lapis & $\begin{array}{c}\text { Kedalamsn } \\
(\mathrm{m})\end{array}$ & Jeats Tanah & $\begin{array}{c}\text { Kadar Air } \\
\text { Jemuh } \\
\text { (m3 } 3 \text { m3) }\end{array}$ & 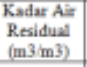 & $\begin{array}{c}\text { Ksat } \\
\text { (midet) }\end{array}$ \\
\hline 1 & $0-2.5$ & $\begin{array}{l}\text { Lempung berpasir (sandy } \\
\text { clapy) }\end{array}$ & 0.42 & 0.042 & $1.4 \mathrm{E}-07$ \\
\hline 2 & $2.5-5$ & $\begin{array}{c}\text { Linm berpasir berkenibal } \\
\text { (sandy sif) }\end{array}$ & 0.45 & 0.045 & $4.50 \mathrm{E}-07$ \\
\hline 3 & $5-10.5$ & $\begin{array}{c}\text { Lanan berpasir berkerikal } \\
\text { (sandy sil) }\end{array}$ & 0.45 & 0.045 & $4.50 \mathrm{E}-07$ \\
\hline 4 & $105-145$ & $\begin{array}{l}\text { Pasir bethanau beckenlal } \\
\text { (sily sand) }\end{array}$ & 0.51 & 0.051 & $500 \mathrm{E}-07$ \\
\hline 5 & $14.5-20$ & $\begin{array}{l}\text { Lempung berlansu } \\
\text { betposir (sandy vilty clay) }\end{array}$ & 0.42 & 0.042 & $1.40 \mathrm{E}-07$ \\
\hline
\end{tabular}

(Sumber : Analisa dan Perhitungan)

Tabel 2. Data Masukan Dalam Slope/W

\begin{tabular}{|c|c|c|c|c|c|}
\hline \multirow{2}{*}{ Lapis } & \multirow{2}{*}{$\phi\left({ }^{\circ}\right)$} & \multicolumn{2}{|c|}{ Kohesi / } & \multicolumn{2}{c|}{ Berat Isi Tanah $/ \gamma \mathrm{w}$} \\
\cline { 3 - 6 } & & $(\mathrm{kg} / \mathrm{cm} 2)$ & $(\mathrm{kPa})$ & $(\mathrm{gr} / \mathrm{cm} 3)$ & $(\mathrm{kN} / \mathrm{m} 3)$ \\
\hline 1 & 11 & 0.16 & 16 & 1,63 & 16,3 \\
\hline 2 & 9 & 0.15 & 15 & 1,497 & 14.97 \\
\hline 3 & 11 & 0.11 & 11.36 & 0,877 & 8.77 \\
\hline 4 & 12 & 0.13 & 12.80 & 0,893 & 8.93 \\
\hline 5 & 10 & 0.15 & 14.86 & 1,29 & 12,86 \\
\hline
\end{tabular}

(Sumber : Analisa dan Perhitungan)

\section{Pemodelan Hujan}

Analisis hujan pada studi ini merujuk pada Pramusandi, 2010 dalam menganalisis pengaruh variasi hujan, dilakukan pemodelan hujan dalam tujuh model. Oleh karena itu pada studi ini pemodelan hujan dibuat dalam empat model, antara lain :

Tabel 3. Pemodelan Hujan

\begin{tabular}{|c|c|c|}
\hline $\begin{array}{c}\text { Model } \\
\text { Hujan }\end{array}$ & Tipe Hujan & $\begin{array}{c}\text { Total } \\
\text { Durasi }\end{array}$ \\
\hline I & Tanpa hujan & 0 \\
\hline II & $\begin{array}{c}\text { Hujan eksisting sebelum } \\
\text { dan sesudah longsor }\end{array}$ & 7 hari \\
\hline III & $\begin{array}{c}\text { Hujan selama 10 tahun } \\
\text { (2005 - 2015) }\end{array}$ & $\begin{array}{c}960 \\
\text { hari }\end{array}$ \\
\hline IV & Hujan perkiraan & 30 hari \\
\hline
\end{tabular}

(Sumber : Analisa dan Perhitungan)
Litvin (2008), lereng yang diberi lapisan perkerasan mempunyai batasan dalam kapasitas infiltrasi hujan. Hujan dimodelkan dalam persentase sebesar $100 \%, 90 \%, 80 \%$ dan $75 \%$. Oleh karena itu, dalam studi ini hujan juga dimodelkan sesuai penelitian Litvin (2008). Selain itu dalam analisis transient Seep/W tidak bisa mengakomodir hujan yang terjadi pada lapisan shotcrete. Sehingga berdasarkan uraian diatas, hujan diasumsi dengan persentase sebesar $80 \%$.

\section{Hasil Analisis Model Hujan I}

Model hujan I merupakan kondisi awal yang menggambarkan kondisi lereng saat sebelum terjadinya hujan. Model hujan I merupakan initial condition bagi Model II dan III. Model I, menggunakan muka air tanah dalam Seep/W untuk mendapatkan tekanan air pori awal. Untuk mengetahui perubahan tekanan air pori akibat pengaruh hujan seperti pada Gambar 4 berikut :

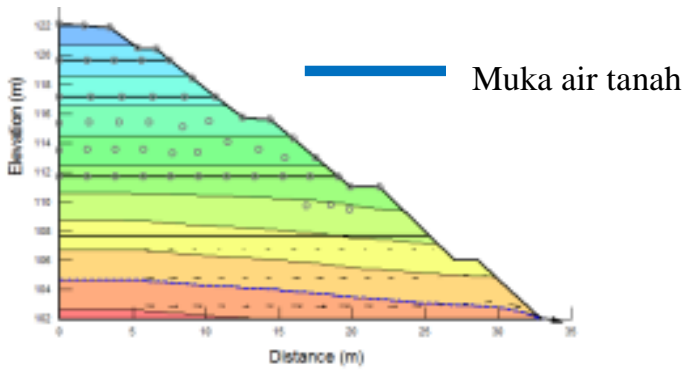

Gambar 4. Kontur tekanan air pori hasil analisis Steady State

Pada elevasi $120 \mathrm{~m}$, terjadi tekanan air pori negatif sebesar $-173 \mathrm{kPa}$. Seiring dengan menurunnya elevasi, tekanan air pori nilainya mendekati 0. Pada elevasi dibawah $105 \mathrm{~m}$ tekanan air pori menjadi positif menjadi 26 $\mathrm{kPa}$. Hal ini dikarenakan terdapat muka air tanah pada elevasi $105 \mathrm{~m}$.

Selanjutnya tekanan air pori tersebut akan dihitung oleh Slope/ $W$ untuk mendapatkan angka keamanan lereng. Slope/ $W$ sebagai "anak" menggunakan hasil dari Seep/W berupa tekanan air pori sebagai input dalam analisa stabilitas. Analisa slip surface dengan metode grid and radius. Ada tiga metode yang digunakan dalam analisa stabilitas lereng, yaitu Bishop, Fellenius, dan Morgenstern-Price.

Berikut ini hasil analisis menggunakan Slope/ $W$ dengan berbagai metode seperti pada tabel berikut : 
Tabel 4. Angka Keamanan Hasil Analisis Steady State

\begin{tabular}{|c|c|}
\hline Metode & Angka Keamanan \\
\hline \hline Bishop & 1,107 \\
\hline Fellenius & 1,061 \\
\hline Morgensten Price & 1,101 \\
\hline
\end{tabular}

(Sumber : Analisa dan Perhitungan)

\section{Hasil Analisis Model Hujan II}

Pada model ini intensitas hujan diinput mulai tanggal 31 Januari 2015 sampai dengan 6 Februari 2015 sebagai unit fluk boundary condition. Tekanan air pori pada Gambar 3 diatas dijadikan input pada analisis model hujan II ini sebagai initial condition.

Untuk model hujan II ini pohon analisisnya seperti gambar berikut :

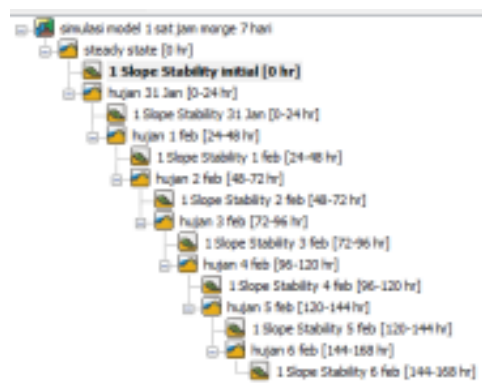

Gambar 5. Pohon Analisis Untuk Model Hujan II

Hasil analisis untuk model hujan II apabila digambarkan dalam bentuk grafik sebagai berikut :

a. Metode Bishop

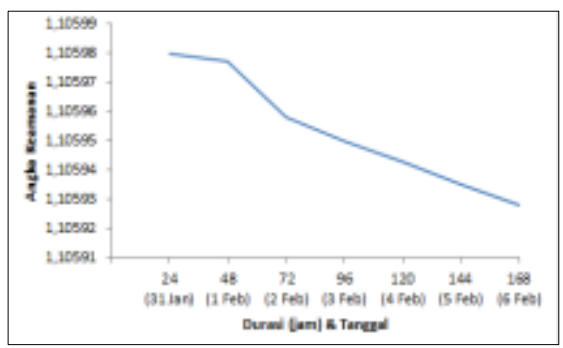

Gambar 6. Grafik Hubungan Angka

Keamanan dan Durasi

b. Metode Fellenius

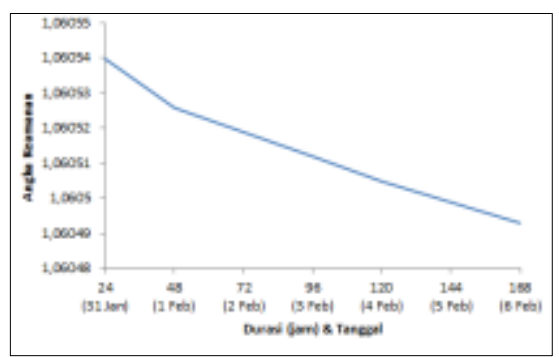

Gambar 7. Grafik Hubungan Angka

Keamanan dan Durasi c. Metode Morgensten Price

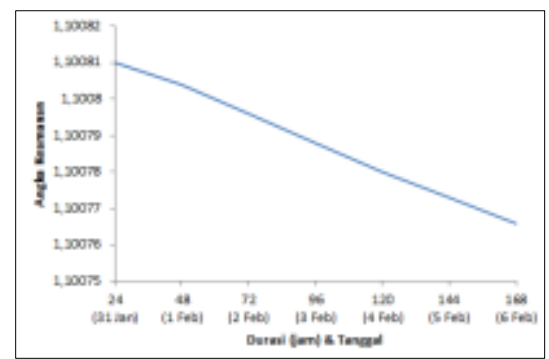

Gambar 8. Grafik Hubungan Angka Keamanan dan Durasi

Dari gambar diatas bisa diketahui bahwa angka kemanan semakin menurun dengan bertambahnya durasi. Durasi hujan memegang peranan yang sangat penting. Berdasarkan grafik tersebut dapat disimpulkan bahwa nilai angka keamanan tidak hanya bergantung pada intensitas hujan, namun durasi hujan juga berpengaruh terhadap penurunan angka keamanan.

\section{Hasil Analisis Model Hujan III}

Pada model hujan III menggunakan data hujan selama 10 tahun $(2005$ - 2015). Data hujan ini dihitung rata-ratanya untuk empat stasiun hujan, kemudian dikelompokkan dalam beberapa interval dan dihitung intensitasnya. Intensitas tersebut dimasukkan dalam Geostudio dan didapatkan angka keamanan.

Selanjutnya angka keamanan hasil analisa tersebut dibuat dalam grafik hubungan antara intensitas hujan dan angka keamanan untuk masing-masing metode. Berikut ini grafik hubungan antara intensitas hujan dan angka keamanan :

\section{a. Metode Bishop}

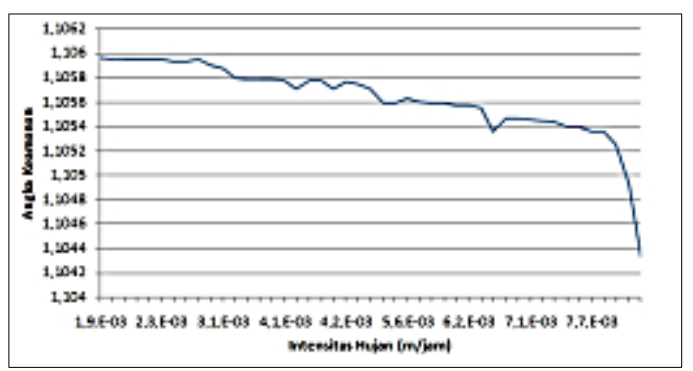

Gambar 9. Grafik Hubungan Antara Intensitas Hujan Dan Angka Keamanan 
b. Metode Fellenius

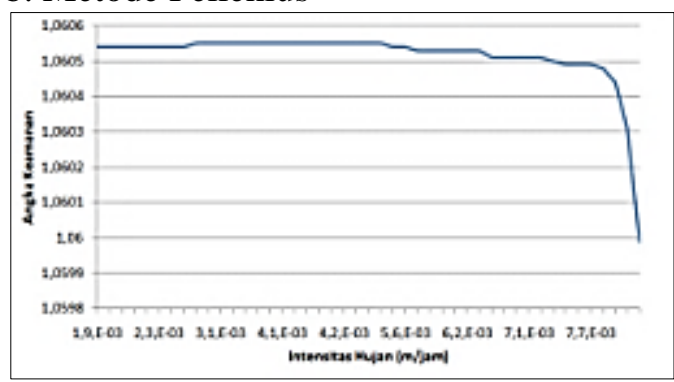

Gambar 10. Grafik Hubungan Antara Intensitas Hujan Dan Angka Keamanan

\section{c. Metode Morgenstren - Price}

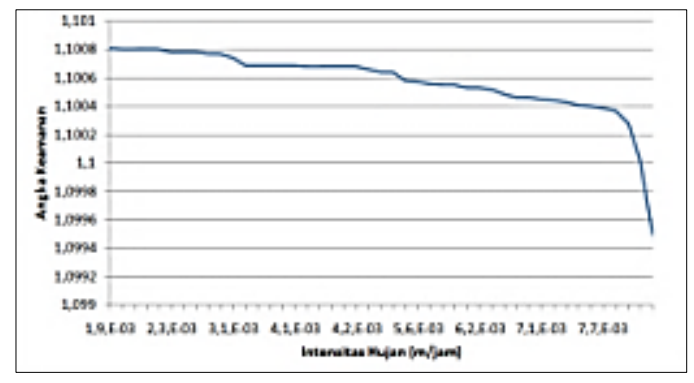

Gambar 11. Grafik Hubungan Antara Intensitas Hujan Dan Angka Keamanan

Berdasarkan hasil analisis pengaruh hujan pada stabilitas lereng menggunakan metode Bishop, Fellenius dan Morgenstern Price, semakin tinggi nilai intensitas hujan, angka keamanannya semakin menurun. Menurut metode Bishop, Fellenius dan Morgenstern - Price pada intensitas $0.0019 \mathrm{~m} / \mathrm{jam}$, angka keamanan lereng dengan nilai tertinggi. Semakin besar intensitasnya menurun, angka keamanan juga turun dengan kemiringan relatif landai. Saat intensitas $0.0077 \mathrm{~m} / \mathrm{jam}$, angka keamanan menurun drastis. Nilai intensitas ini merupakan nilai maksimal dimana setelah intensitas ini tercapai, nilai angka keamanannya tidak bisa berkurang lagi, karena sudah mencapai nilai minimal. Hal ini menunjukkan bahwa, hujan mempunyai pengaruh pada stabilitas lereng.

\section{Perbaikan Lereng Akibat Longsor}

Longsor yang terjadi pada tanggal 3 Februari 2015 memerlukan penanganan secara struktural. Oleh karena itu dalam penelitian ini, penanganan yang akan direncanakan adalah dengan bored pile dan soil nailing. Berdasarkan hasil analisis pada model hujan II, metode analisis yang menghasilkan angka keamanan terkecil adalah metode Fellenius. Namun dalam perencanaan penanganan ke- longsoran membutuhkan hasil analisis berupa shear force atau gaya geser. Gaya geser ini tidak dihasilkan dalam analisis menggunakan metode Fellenius. Oleh karena itu perencanaan penanganan dalam penelitian ini menggunakan metode dengan angka keamanan terendah nomor dua setelah metode Fellenius. Metode analisis yang digunakan adalah Morgenstren-Price. Hasil analisis metode tersebut terdapat gaya geser yang dibutuhkan dalam perencanaan penanganan kelongsoran

\section{Bored Pile}

Perencanaan bored pile pada penelitian ini mengacu pada penelitian terdahulu oleh Anwari (2016). Dimensi bored pile yang didapatkan sebagai berikut :
- Diameter (D)
$=0,8 \mathrm{~m}$

- Jarak antar bored pile $=1 \mathrm{~m}$

Selain dari data-data teknis di atas maka yang perlu diperhatikan juga adalah nilai inputan shear force karena sangat berpengaruh pada nilai faktor keamanan lereng. Nilai gaya geser mengacu pada hasil analisis sebelum perkuatan dengan bored pile. Semakin kecil inputan nilai shear force maka semakin kecil pula nilai faktor keamanan lereng (Fallo, 2016).

Nilai inputan shear force ditentukan berdasarkan letak dari bored pile berada pada slice atau irisan dari radius kelongsoran lereng tersebut. Bored pile diletakkan pada lokasi dengan gaya geser maksimum. Pemodelan yang digunakan adalah model hujan II saat terjadinya longsor, yaitu tanggal 3 Februari 2015.

Berdasarkan hasil analisis, angka keamanan lereng sebelum diperkuat adalah 1,100788. Setelah pemasangan bored pile dengan diameter $80 \mathrm{~cm}$, kedalaman 11,4 m, faktor reduksi geser 1,5 dan jarak antar tiang sebesar $1 \mathrm{~m}$, didapatkan angka keamanan lereng meningkat menjadi 1,465244. Angka keamanan tersebut sudah memenuhi standar minimal angka keamanan dalam Permen PU 2007. Sehingga lereng dalam kondisi stabil setelah pemasangan bored pile. Bored pile ini dipasang memanjang $100 \mathrm{~m}$ sepanjang longsoran terjadi.

Perhitungan analisis harga satuan pekerjaan ini mengacu pada AHSP (Analisa Harga Satuan Pekerjaan) Bidang Bina Marga. Dalam AHSP, harga bored pile dengan diameter $80 \mathrm{~cm}$, adalah Rp 2.421.239,94 per 
m'. Biaya perbaikan lereng dengan perkuatan bored pile yang mempunyai panjang total 1151,4 m adalah Rp. 3.066.597.000,00.

\section{Soil Nailing}

Penanganan kelongsoran dengan bored pile merupakan metode penanganan secara eksternal. Alternatif perbaikan kelongsoran pada tol Gempol - Pandaan adalah dengan memperbaiki struktur tanah maupun memperkuat lapisan permukaannya. Salah satu caranya dengan metode soil nailing.

Data konstruksi soil nailing

- Diameter baja ulir =0,032 $\mathrm{m}$

- Jumlah nail yang dipakai $=4 \mathrm{~m}$

- Spasi jarak nail = $2 \mathrm{~m}$

- Tensile capacity $\left(R_{T}\right)=418 \mathrm{kN}$

Menurut Amit Prashant et al. (2010) dalam risetnya mengenai Soil nailing for Stabilization of Steep Slopes Near Railway Tracks, untuk kondisi tanah Sandy Silt maka nilai "Pullout Resistance (F/Area)" yang digunakan ialah $100 \mathrm{kPa}$.

Berdasarkan hasil analisis, angka keamanan lereng sebelum diperkuat adalah 1,100788. Setelah pemasangan soil nailing, didapatkan angka keamanan lereng meningkat menjadi 1,555921. Angka keamanan tersebut sudah memenuhi standar minimal angka keamanan Permen PU 2007 maupun angka keamanan standar untuk nail dari FHWA. Sehingga lereng bisa dikatakan dalam kondisi stabil setelah pemasangan soil nailing. Soil nailing ini dipasang memanjang $100 \mathrm{~m}$ sepanjang longsoran terjadi.

Perhitungan analisis harga satuan pekerjaan ini mengacu pada AHSP (Analisa Harga Satuan Pekerjaan). Dalam AHSP, harga soil nailing dengan bond diameter $32 \mathrm{~cm}$, adalah Rp 711.107 per m'. Total biaya perbaikan lereng dengan soil nailing yang mempunyai panjang total untuk keempat nail 2478,6 m adalah Rp. 1.938.804.000,00.

\section{Pemilihan Metode Penanganan}

Hasil analisis perkutan lereng diatas baik dengan metode bored pile maupun soil nailing mempunyai kelebihan dan kekurangan masing-masing. Dalam penelitian ini, pemilihan metode penanganan berdasarkan pada angka keamanan yang maksimum dan biaya yang minimum. Metode penanganan yang dapat digunakan adalah soil nailing dengan pertimbangan memiliki angka keama- nan relatif lebih besar dan biaya yang relatif lebih rendah daripada perkuatan dengan bored pile.

\section{Hasil Analisis Model Hujan IV}

Perkiraan hujan sebagai ambang batas aman hujan sangat dibutuhkan sebagai Early Warning System pada penelitian ini. Penelitian ini menganalisis kondisi lereng sebelum diperkuat, kemudian diberikan perkuatan dan selanjutnya setelah diperkuat, diuji lagi dengan hujan perkiraan. Hujan perkiraan dibuat sedemikian rupa sehingga meskipun lereng sudah diperkuat tetapi lereng tersebut masih bisa longsor apabila diberi hujan perkiraan ini. Hujan perkiraan ini merupakan sistem peringatan dini akan adanya longsor.

Dalam Geo-Slope, "Why Do Slope Become Unstable After Rainfall Events?" disebutkan bahwa lereng menjadi tidak stabil ketika mendapat hujan sebesar 23 inci selama 9 bulan diikuti hujan sebesar 9 inci selama 4 hari. Sementara itu menurut Tohari dalam Sarah (2011), hujan pemicu gerakan tanah di lokasi penelitian memiliki nilai kritikal minimum intensitas sebesar $22 \mathrm{~mm} / \mathrm{jam}$ dengan durasi minimum sebesar 22 jam, yang dicirikan oleh total hujan sebesar 428,56 mm yang dapat dihasilkan oleh hujan selama 23 hari. Sarah (2011), gerakan tanah pada lereng tidak terasosiasi oleh curah hujan tunggal pada kejadian longsor pada tanggal 22 Desember 2004, tetapi lebih cenderung disebabkan oleh total air hujan selama 22 hari (1 Desember 2004 - 22 Desember 2004) yang mencapai $291 \mathrm{~mm}$.

Curah hujan dari semua stasiun diamati yang mempunyai kecenderungan nilai diatas 50 - 100. Karena nilai curah hujan tersebut merupakan hujan dengan interval tinggi. Dari pengamatan diperoleh hujan dengan kisaran nilai $60 \mathrm{~mm}$ dan $100 \mathrm{~mm}$ yang sering terjadi pada lokasi studi. Kejadian hujan dalam satu tahun dari pengamatan didapatkan untuk hujan $60 \mathrm{~mm}$ terjadi selama 6 kali. Dan hujan $100 \mathrm{~mm}$ terjadi selama 6 kali. Hujan diinput dalam Seep/W berupa intensitas hujan jamjam an. Selama 1 bulan, 30 hari, dan 720 jam, hujan diinput dengan konfigurasi tertentu melibatkan kejadian hujan $60 \mathrm{~mm}$ selama 6 kali dan hujan $100 \mathrm{~mm}$ selama 6 kali.

Berikut ini hasil simulasi Slope/W untuk model hujan IV : 


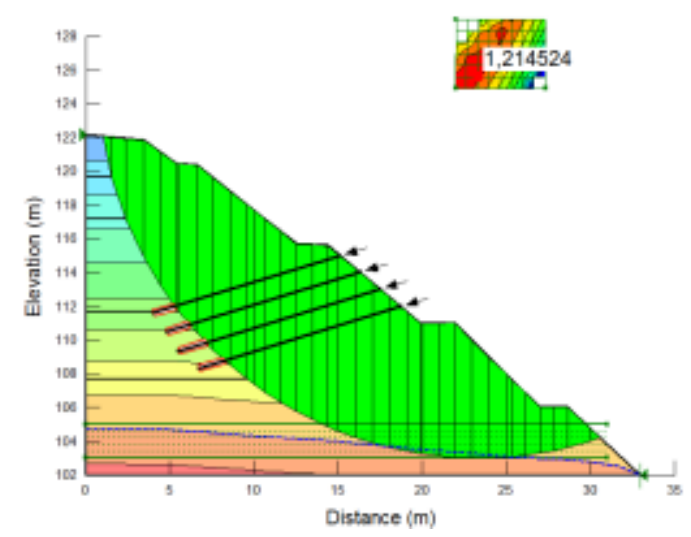

Gambar 12. Angka keamanan Hasil Analisis Model Hujan IV

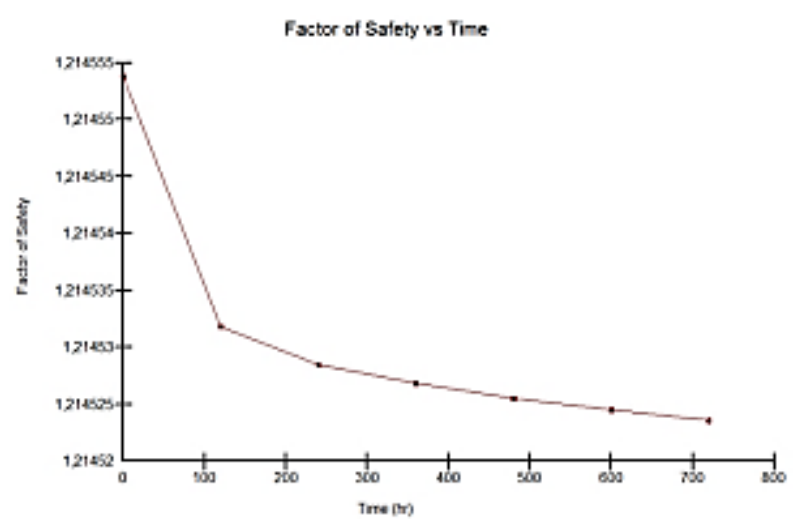

Gambar 13. Grafik Hubungan Intesitas Hujan dan Angka Keamanan

Angka keamanan sebesar 1,214524 mendekati 1,2. Kombinasi hujan $60 \mathrm{~mm}$ dan hujan $100 \mathrm{~mm}$ selama 30 hari yang menghasilkan total hujan sebesar $960 \mathrm{~mm}$ dapat digunakan sebagai ambang batas keamanan. Prediksi kelongsoran pada jalan tol Gempol - Pandaan setelah perbaikan dengan perkuatan soil nailing disebabkan oleh total hujan lebih besar dari $960 \mathrm{~mm}$ selama 30 hari.

Sehingga ambang batas aman hujan untuk lereng setelah diperkuat adalah sebelum tercapainya total hujan lebih besar dari 960 mm selama 30 hari.

\section{KESIMPULAN}

Berdasarkan hasil analisa dan pembahasan yang telah dilakukan, maka dapat diambil kesimpulan sebagai berikut:

1. Analisis stabilitas lereng di jalan tol Gempol - Pandaan dengan metode Bishop, Fellenius dan Morgenstern - Price untuk mendapatkan angka keamanan masingmasing metode. Stabilitas lereng didapatkan dari masing-masing nilai intensitas hujan tiga hari sebelum dan tiga hari sesudah longsor. Menurut metode Bishop, angka keamanan tanggal 31 Januari adalah 1,10598, tanggal 3 Februari 1,10594, tanggal 6 Februari 1,10593. Menurut metode Fellenius, angka keamanan tanggal 31 Januari 1,06054. Saat longsor tanggal 3 Februari adalah 1,060505, tanggal 6 Februari adalah 1,060493. Menurut metode Morgenstren - Price, angka keamanan tanggal 31 Januari adalah 1,10081, tanggal 3 Februari adalah 1,100788, tanggal 6 Februari adalah 1,100766.

2. Berdasarkan hasil analisis dengan metode Bishop, Fellenius dan Morgenstern - Price, semakin besar interval hujan, angka keamanan semakin kecil, semakin besar intensitas hujan, semakin kecil angka keamanannya. Menurut metode Bishop, Fellenius dan Morgenstern - Price pada intensitas $0.0019 \mathrm{~m} / \mathrm{jam}$, angka keamanan lereng dengan nilai tertinggi. Semakin besar intensitasnya menurun, angka keamanan juga turun dengan kemiringan relatif landai. Saat intensitas $0.0077 \mathrm{~m} / \mathrm{jam}$, angka keamanan menurun drastis. Nilai intensitas ini merupakan nilai maksimal dimana setelah intensitas ini tercapai, nilai angka keamanannya tidak bisa berkurang lagi, karena sudah mencapai nilai minimal. Hal ini menunjukkan bahwa nilai intensitas hujan berpengaruh pada penurunan stabilitas lereng.

3. Metode analisis bored pile mempunyai angka keamanan sebesar 1,465244 dengan biaya sebesar Rp. 3.066.597.000,00. Sedangkan metode soil nailing mempunyai angka keamanan relatif lebih besar dan biaya yang relatif lebih rendah daripada perkuatan dengan bored pile. Angka keamanan dengan perkuatan soil nailing sebesar 1,555921 dan biaya perbaikan sebesar Rp.1.938.804.000,00. Soil nailing juga memiliki keunggulan dalam hal aplikasi di lapangan selain mudah juga lebih ramah lingkungan.

4. Simulasi untuk mendapatkan ambang batas intensitas dan durasi hujan yang aman dilakukan untuk sistem peringatan dini kelongsoran. Hasil simulasi didapatkan hujan yang terjadi selama 30 hari dengan total hujan $960 \mathrm{~mm}$ menyebabkan angka keamanan lereng menjadi 1,214524. Angka keamanan tersebut mendekati nilai 1,2. Sistem peringatan dini di lokasi studi dapat berupa alat Early Warning System dan 
berupa terpal untuk melindungi pengguna jalan dari bahaya kelongsoran.

\section{DAFTAR PUSTAKA}

Anwari, SRN. 2016. Alternatif Sistem Perbaikan Longsoran Lereng Di Lokasi Gesing Jalan Tol Gempol-Pandaan Sta $6+275$ S/D 6+375. Skripsi. Tidak dipublikasikan. Surabaya: Institut Teknologi Sepuluh November.

Dinas Pekerjaan Umum Bina Marga Kabupaten Pasuruan. www.binamarga.pasuruankab.go.id. (diakses 2 Februari 2016)

Fallo, D.A. 2016. Studi Tentang Alternatif Struktur Penahan Untuk Mengatasi Masalah Pergerakan Tanah Di Pltp Ulumbu Kecamatan Satar Mese Kabupaten Manggarai Tengah Propinsi Ntt. Skripsi. Malang : Universitas Brawijaya.

FHWA. 2010. Drilled Shafts: Construction Procedures and LRFD Design Methods. Amerika. NHI

FHWA. 2015. Soil Nail Wall Reference Manual. Amerika. NHI

Hardiyatmo, H. C. 2012. Tanah Longsor \& Erosi. Yogyakarta: Gadjah Mada University Press.

Hidayat, R., Subiyantoro, A, 2015. Penanganan Longsor Pada Lereng Jalan Tol Gempol - Pandaan Km 51, Pasuruan, Jawa Timur.

International, Geo-Slope. Why Do Slope Become Unstable After Rainfall Events?
Karnawati, Dwikorita. 2010. Bencana Alam Gerakan Massa Tanah di Indonesia dan Upaya Penanggulangannya. Yogyakarta: Gajah Mada University Press.

Kementrian Pekerjaan Umum dan Perumahan Rakyat, Direktorat Jenderal Bina Marga. 2016. Analisa Harga Satuan Pekerjaan.

Litvin, E. 2008. Numerical Analysis Of The Effect Of Rainfall Infiltration On Slope Stability. Atkin.

Peraturan Menteri Pekerjaan Umum. 2007. Pedoman Penataan Ruang Kawasan Rawan Bencana Longsor. Jakarta : Kementrian Pekerjaan Umum.

Pramusandi, S. 2011. Penentuan Sifat Teknis Tanah Jenuh Sebagian Dan Analisis Deformasi Lereng Akibat Pengaruh Variasi Hujan. Tesis. Yogyakarta : Universitas Gajah Mada.

Prashant, A. et all. 2010. Soil nailing For Stabilization Of Steep Slopes Near Railway Tracks. Indian Institute Of Technology Kanpur.

Sarah, Dwi. 2011. Studi Karakteristik Curah Hujan Pemicu Gerakan Tanah Di Daerah Cibeber, Cianjur Selatan Jawa Barat. Buletin Geologi Tata Lingkungan (Bulletin of Environmental Geology). Bandung.

Soemarto, C. 1995. Hidrologi Teknik. Jakarta: Erlangga.

Subiyanti, H. 2011. Analisis Kelongsoran Lereng Akibat Pengaruh Tekanan Air Pori di Saluran Induk Kalibawang Kulonprogo. Jurnal Ilmiah Semesta Teknika, 25. 